\title{
The Relics of Witchcraft in Italy in the Work of Charles Godfrey Leland (Comments on the Origin of WICCA)
}

\author{
Giuseppe Maiello \\ University of Finance and Administration
}

\begin{abstract}
The study presents the activities of the American folklorist Charles Godfrey Leland (1824-1903) in Italy. Leland's aim was to find relics of the ancient religion of the Etruscans and the ancient Romans among the peasants and shepherds living in the upper regions of Apennine, between Florence and Bologna. Collections of legends and tales of the local inhabitants of Apennine published by Ch. G. Leland in the 1890s, became the primary sources which the current representatives of the Wicca religious movement refer to. Leland's ethnographic activities can be described as quite controversial, and have found very little response not only in the Italy at the time, but also in the American academic space. The contribution does not attempt to give Wicca followers any answer to the question if the current Wicca may still refer to Leland's work or not, but wants to provide a critical view of his personage and his method of collecting data.
\end{abstract}

\section{Keywords}

Charles Godfrey Leland, Witchcraft, Italian Folklore, Wicca

\section{Contact address}

doc. dott. Giuseppe Maiello, PhD et Ph.D., University of Finance and Administration, Estonská 500, 10100 Prague 10, Czech Republic

e-mail:27773@mail.vsfs.cz

\section{Introduction}

The Apennine peninsula had always been a place of interest for foreign travelers and intellectuals. When leafing through, for example, the pages of the account of William Moens (1833-1904), a British traveler kidnapped in southern Italy in 1865 by a band of brigands, 
we have beautiful descriptions of the life of these men as if carried out by a professional anthropologist of the twentieth century. ${ }^{1}$

If one does not take into account collections prior to the unification of Italy, worthy of mention is the publication in Vienna in 1864 of a collection of Venetian songs, translated into German. ${ }^{2}$ Also in Vienna, a literary historian Marcus Landau (1837-1918) published an extensive study in 1875 dedicated to the origins and development of Italian novellas. ${ }^{3}$ Thomas Frederick Crane (1844-1927), professor of Romance Languages at Cornell University, published an accurate collection of folk tales of the Italian peninsula in 1885, including an accurate historical analysis of the studies of the oral literature of Italian peoples. ${ }^{4}$

Finally, a number of collections, dedicated in this case to the folk tales of Florence and the Tuscan Apennines, were published in the 1890s by the American folklorist Charles Godfrey Leland (1824-1903). ${ }^{5}$ These collections were of great importance over the following decades, becoming the primary source of a continually growing world religious movement, Wicca, as well as other minor neo-pagan groups. ${ }^{6}$

\section{Charles Godfrey Leland}

According to his niece and biographer, Elizabeth Robins Pennell, Charles Godfrey Leland first heard about witchcraft from an elderly Dutch nurse who lived near his rich family. In addition, two Irish maids told him about ancient fairy tales from their lands, and finally several African-American cooks told him about Voodoo. In his youth, Leland studied the culture of the Gypsies and of the native peoples of North America. After completing his linguistic studies at Princeton University, he took his first trip to Europe. First to Germany, where he visited the universities of Heidelberg and Munich, then to France, where he visited the Sorbonne and where he participated in the 1848 revolution. In Italy we find him 20 years later, in Florence, which represented a starting point for a series of surveys in the Tuscan countryside, but above all in the direction of the mountainous areas on the border with Emilia-Romagna. His aim was to collect documentary material concerning, in particular, the magic and beliefs of the inhabitants of the Apennines. ${ }^{7}$

Leland collected a large amount of material from Tuscany and the Tuscan Apennines. He then had it translated first from the local dialects into Italian and then himself translated

\footnotetext{
${ }^{1}$ William J. C. Moens, English Travellers and Italian Brigands, (London: Hurst and Blackett, 1866).

${ }^{2}$ Georg Widter and Adolf Wolf, Volkslieder aus Venetien, (Wien: K. Gerold's Sohn, 1864).

${ }^{3}$ Marcus Landau, Beiträge zur Geschichte der italienischen Novelle, (Wien: Rosner, 1875).

${ }^{4}$ Thomas Frederick Crane, Italian Popular Tales, (Boston-New York: Houghton, Mifflin and Co., 1885). The book includes a dedication to Giuseppe Pitrè, at that time very well reviewed especially in Englishlanguage journals.

${ }^{5}$ Charles Godfrey Leland, Etruscan Roman Remains in Popular Tradition, (London: Unwin, 1892); Legends of Florence: Collected from the People. Vol. I., (Detroit: Singing Tree Press, 1885); Legends of Florence, Collected from the people. Vol. II., (London: Nutt, 1886); Aradia, or the Gospel of the Witches, (London: Nutt, 1899).

${ }^{6}$ Giordano Berti, Storia della stregoneria, (Milano: Mondadori, 2010).

${ }^{7}$ Elizabeth Robins Pennel, Charles Godfrey Leland a Biography, (New York: Constable \& Co., 1906).
} 
it into English and organized everything into four volumes of study. Already in the first work, entitled Etruscan Roman Remains in Popular Tradition, in addition to describing the magical practices of the Apennine people, Leland took a step that placed him in opposition with the academic world and which still arouses controversy. According to Leland, a genuine and independent religion was still preserved in the nineteenth century in the area he studied. This religion was called witchcraft [stregheria] by the locals, while he himself referred to it as the old religion [La vecchia religione]. According to Leland, it was "something more than sorcery and something less than faith".

It consists in remains of a mythology of spirits, the principal of whom preserve the names and attributes of the old Etruscan gods, such as Tinia or Jupiter, Faflon, or Bacchus, and Teramo (in Etruscan Turms) or Mercury. With these there still exist, in a few memories, the most ancient Roman rural deities, such as Silvanus, Palus, Pan, and the Fauns. To all of these invocations or prayers in rude metrical form are still addressed, or are at least preserved, and there are many stories current regarding them. All of these names, with their attributes, descriptions of spirits or gods, invocations and legends, will be found in this work. ${ }^{8}$

What makes Leland a very important figure for contemporary witchcraft, or Wicca, but at the same time less reliable from the point of view of ethnographic rigor, is the fact that he himself is believed to have been joined this old religion in 1886, thanks to his primary informant, whom Leland calls Maddalena of Rocca Casciano. ${ }^{9}$ Heated debates still persist at present, which also have repercussions in scholarly circles, as to whether the young and beautiful informer Maddalena was actually a witch or a mere charlatan eager for the money that Leland gave her. Whatever the case, it was also a question which occurred to Leland, who, however, dissolved his doubts in 1891 and considered the manuscript given to him by Maddalena in that same year, where all her "magical knowledge" was reported. The written testimonies of Maddalena therefore served as the basis for the aforementioned Etruscan Roman remains and for the following two books by Leland's, collected under the sole title of Legends of Florence.

Leland received another manuscript on 1 January 1897 which he published two years later under the title Aradia, or the Gospel of the Witches of Italy. Aradia is the modified name of Herodiada, who was referred to as the chieftain of European witches, synonymous with Diana, ${ }^{10}$ in the Middle Ages or, at least for Leland's informants, her daughter. And it is in fact to Diana that the first chapter of the Gospel is dedicated, called "How Diana gave birth to Aradia", in order for her to teach the world about resistance and magic. If it is true that Leland did not perform any kind of manipulation on the manuscript, apart from the translation, then he had to have been extremely pleased to have discovered that sorcery was not merely a millennial practice, that was still preserved in that particular corner of

\footnotetext{
${ }^{8}$ Leland, Etruscan Roman Remains, 2.

${ }^{9}$ Leland, Legends of Florence II, 141. The village which Leland refers to is now called Rocca San Casciano. As of 1923 it is no longer part of the Tuscany region, but of the Emilia-Romagna region (Province of Forli-Cesena).

${ }^{10}$ Carlo Ginzburg, Storia notturna. Una decifrazione del sabba, (Torino: Einaudi, 1989).
} 
Europe, but that it also represented a form of social resistance to the abuses of the rich. Leland had indeed been an anarchist in his youth and did not appear to have rejected his political ideas, despite his interest in Italian ethnology. ${ }^{11}$

\section{Discussion}

What makes the majority of scholars wary concerning the works of Leland related to his Italian period is the fact that the numerous magic formulas collected by Leland were published by him alone and by no one else. Moreover, another element of doubt derives from the fact that Magdalene took 11 years to provide Leland with the manuscript of the Gospel he had requested and of which he had initially heard of in 1886. This circumstance is a point in favor of the originality of the manuscript and is supported above all by the followers of Wicca, such as, for example, the Italian-American pagan scholar Raven Grimassi. Maddalena was in fact extremely poor, and for Grimassi and his followers would not have waited 11 years when faced with the prospect of earning money immediately. ${ }^{12}$

The works of Leland did not receive a favorable reception in the academic space. The theory of the survival of Etruscan myths in Tuscan-Romance folklore only survived in Italy up until the 1920s, having been accepted earlier even by King Victor Emmanuel III. The major Italian anthropologist of the day, Raffaele Corso, dismissed in contrast the hypothesis as "shaky" and "cockeyed" and did not hesitate to criticize the superficiality of the King in themes of ethnography. ${ }^{13}$

During debates in the 1950s within the Wicca movement as to what types of rites to use in their practices, the great priestess Doreen Valiente (1922-1999) decided to return to Aradia as a source of greater reliability for contemporary witchcraft practices. ${ }^{14}$

Carlo Ginzburg, in contrast, who proved to be quite open to the possibility of considering the stories of witches in his main study on witchcraft, prefers not to mention the studies of Charles Godfrey Leland of the end of the nineteenth century. ${ }^{15}$

\section{Conclusion}

It is difficult to take a precise position regarding the origins of Wicca. From the point of view of the followers of this religious movement, which in the twentieth century has

\footnotetext{
${ }^{11}$ The romantic idea that witchcraft was a form of popular revolt against the abuses of power had been formulated as early as 1862 by the celebrated French historian Jules Michelet (1798-1874). None of the works of Leland which we have consulted make mention of the work of Michelet - La Sorcière - in which European witchcraft was analyzed and the aforementioned social theory was expressed.

${ }^{12}$ Raven Grimassi, "Maddalena Taluti. A Witch of Old Italy”, The Cauldron Magazine 156 (2015).

${ }^{13}$ Raffaele Corso, "Presunti miti etruschi nel folklore della Romagna-Toscana." Il folklore italiano. Archivio per la raccolta e lo studio delle tradizioni popolari italiane IV (1929), 1-11.

${ }_{14}$ Berti, Storia della stregoneria, 208.

${ }^{15}$ Ginzburg, Storia notturna.
} 
gone through various stages of development and heated discussions concerning what in theological language would be called orthodoxy and heterodoxy, references to the studies of Leland represent the highest level of connection with the pagan roots of European culture. Not all the Wiccans, however, know G. Leland, but this is an element in his favor as he undoubtedly is of interest due his eccentric character and his assiduity as a scholar.

I am of the opinion, however, that Leland has too hastily interpreted the remains of Apennine oral culture. This is not to dispute, however, the question of whether contemporary Wicca has a legacy for its existence. Many parts of western society, in its spirit of tolerance, consider Wicca to be a solidly based religious movement. If the basics of Wicca do not have, however, a solid scientific basis, it would obviously not be the first religious movement to find itself in this ambiguous situation.

\section{Bibliography}

Berti, Giordano. Storia della stregoneria. Milano: Mondadori, 2010.

Corso, Raffaele. "Presunti miti etruschi nel folklore della Romagna-Toscana." Il folklore italiano. Archivio per la raccolta e lo studio delle tradizioni popolari italiane IV (1929), 1-11.

Crane, Thomas Frederick. Italian Popular Tales. Boston-New York: Houghton, Mifflin and Co., 1885.

Ginzburg, Carlo. Storia notturna. Una decifrazione del sabba. Torino: Einaudi, 1989.

Grimassi, Raven. «Maddalena Taluti. A Witch of Old Italy.» The Cauldron Magazine. spring 1995. http:// www.the-cauldron.org.uk/Resources/Maddalena.pdf.

Landau, Marcus. Beiträge zur Geschichte der italienischen Novelle. Wien: Rosner, 1875.

Leland, Charles Godfrey. Etruscan Roman Remains in Popular Tradition. London: Unwin, 1892.

-. Aradia, or the Gospel of the Witches. London: Nutt, 1899.

—. Legends of Florence, Collected from the People. Vol. II. London: Nutt, 1886.

-. Legends of Florence: Collected from the People. Vol. I., Detroit: Singing Tree Press, 1885.

Michelet, Jules. La Sorcière. Paris: Dentu, 1862.

Moens, William J. C. English Travellers and Italian Brigands. London: Hurst and Blackett, 1866.

Robins Pennel, Elizabeth. Charles Godfrey Leland a Biography. New York: Constable \& Co., 1906.

Widter, Georg, and Adolf Wolf. Volkslieder aus Venetien. Wien: K. Gerold's Sohn, 1864. 